\title{
Genetic predisposition in pediatric oncology
}

Doina Paula Pruteanu ${ }^{1,2}$, Diana Elena Olteanu ${ }^{1}$, Rodica Cosnarovici ${ }^{1}$, Emilia Mihut ${ }^{1}$, Viorica Nagy ${ }^{1,2}$

1) Department of Pediatric Oncology, "Prof. Dr. Ion Chiricuta" Oncology Institute, Cluj-Napoca, Romania

2) Department of Radiation Oncology, Iuliu Hatieganu University of Medicine and Pharmacy, ClujNapoca, Romania
DOI: $10.15386 / \mathrm{mpr}-1576$

Manuscript received: 18.01 .2020

Received in revised form: 10.03 .2020

Accepted: 25.07.2020

Address for correspondence:

pauladpruteanu@gmail.com

This work is licensed under a Creative Commons Attribution-NonCommercialNoDerivatives 4.0 International License

\begin{abstract}
Identifying patients with a genetic predisposition for developing malignant tumors has a significant impact on both the patient and family. Recognition of genetic predisposition, before diagnosing a malignant pathology, may lead to early diagnosis of a neoplasia. Recognition of a genetic predisposition syndrome after the diagnosis of neoplasia can result in a change of treatment plan, a specific follow-up of adverse treatment effects and, of course, a long-term follow-up focusing on the early detection of a second neoplasia.

Responsible for genetic syndromes that predispose individuals to malignant pathology are germline mutations. These mutations are present in all cells of conception, they can be inherited or can occur de novo.

Several mechanisms of inheritance are described: Mendelian autosomal dominant, Mendelian autosomal recessive, X-linked patterns, constitutional chromosomal abnormality and non-Mendelian inheritance.

In the following review we will present the most important genetic syndromes in pediatric oncology.
\end{abstract}

Keywords: pediatric cancer, genetic predisposition to disease, genetic syndromes, germ-line mutation

\section{Introduction}

More than 100 cancerpredisposing genes have been discovered so far [1].

In 1991, Narod et al. published a study analyzing 16,564 patient-files diagnosed with pediatric cancers between 1971-1983, which were reported in the Pediatric Malignant Tumor Registry of Great Britain. In 509 cases $(3.09 \%)$ a genetic disorder was reported, a number that can represent an underestimation of the proportion of cases determined by a genetic mutation, if constitutional abnormalities and other pathologies were incompletely documented in patient files [2]. In the last decades other germline mutations that predispose to cancer have been discovered, therefore the proportion of pediatric cancers with genetic determinism may be higher.

The proportion of malignant tumors with genetic predisposition has wide variations depending on the tumor type. Between $50 \%$ and $80 \%$ of the adrenocortical carcinomas [3,4], $45 \%$ of the optic gliomas [5], $40 \%$ of the retinoblastomas [6], $25 \%$ of the pheochromocytomas [7], $3-5 \%$ of the Wilms tumors[8,9], $1-3 \%$ of the central nervous system tumors[10,11] are determined by genetic factors.

\section{Constitutional chromosomal abnormalities \\ Down syndrome \\ Patients with Down syndrome} (DS) have an estimated cumulative risk to develop leukemia of $2.1 \%$ until the age of 5 , and of $2.7 \%$ until the age of 30 (more than 20 times higher than the general population), however no increased risk for developing solid tumors was reported [12]. Also, approximately $10 \%$ of patients with DS develop a transient myeloproliferative disorder [13]. 
The presence of an additional chromosome 21 in leukemic cells, acquired on the germinal or somatic line, appears to have a leukemogenic effect, trisomy 21 being a common discovery in the karyotype of leukemia cells in patients without DS [14].

The transient myeloproliferative disorder is a form of leukemia, almost exclusively diagnosed in patients with DS and it is characterized by the presence of megakaryoblasts in bone marrow, peripheral blood and liver. The majority of cases are asymptomatic, so that patients in which a routine full blood count has not been performed may remain undiagnosed. The incidence of $10 \%$ described in literature may be an underestimation. However, some patients may present at birth, or shortly after, an impressive clinical picture with massive pleural and pericardial effusions, ascites, massive hepatosplenomegaly with consecutive multiorgan failure, which in most cases is fatal $[15,16]$.

Most cases regress spontaneously in about 3 months [17]. Approximately $30 \%$ of patients with DS and transient myeloproliferative disorder will develop myeloid leukemia associated with Down syndrome in the next 3 years [18]. Some studies have shown that blasts from transient myeloproliferative disorder are clonal, and the same clone is responsible for the development of acute myeloid leukemia associated with DS in a subset of patients $[19,20]$. The somatic mutation of the GATA 1 gene is necessary for the development of the transient myeloproliferative disorder [21]. The consequence of this mutation is uncontrolled proliferation of a subset of megakaryoblasts and impaired megakaryocytic differentiation [22].

Patients with DS have a smaller proportion of lymphoblastic leukemias compared with the general population. This is due to the increased incidence of myeloblastic leukemia until the age of 2. Most patients will develop myeloid leukemia associated with Down syndrome. This subtype is always associated with the GATA 1 mutation.

An important increase in survival for patients with acute myeloblastic leukemia (AML) has been reported in the last years, so that at present an overall survival at 5 years of $75 \%$ is reported, but progression free survival remains low (55\%) at 5 years. In contrast with the general population, patients with DS have the highest progression free survival (68-100\%) from all subgroups of patients with AML [23,24]. Laboratory studies have shown that these amazing results in patients with DS are due to an increased sensitivity of myeloblasts to Cytarabine and Doxorubicine in patients newly diagnosed with AML and DS than in patients with AML without DS [25].

In patients with DS the intensive chemotherapy used to treat patients with AML is associated with a high rate of complications, especially infections and cardiotoxicity; $17.5 \%$ of patients treated with the POG (Pediatric Oncology Group) 9421 protocol with a cumulative dose of Daunorubicine of $135 \mathrm{mg} / \mathrm{m}^{2}$ developed symptomatic cardiomyopathy during or immediately after finishing treatment [26].

Due to the very good survival rates, but with a high rate of complications in these patients with usual treatment protocols, patients with DS and AML are treated today with DS-specific treatment protocols. These treatment protocols are based on cytarabine and lower doses of anthracyclines. The purpose of these treatment protocols is to maintain the good survival rates and to lower the rate and intensity of the adverse reactions.

Results of the international multicentric study ML-DS 2006 were published in 2017: 170 patients with DS and AML were treated with low dose of Etoposide $\left(450 \mathrm{mg} / \mathrm{m}^{2}\right.$ instead of $\left.950 \mathrm{mg} / \mathrm{m}^{2}\right), 4$ instead of 11 intrathecal administration of chemotherapy for the central nervous system prophylaxis and no maintenance treatment. The results obtained were similar to the results obtained in the historical control arm: overall survival at 5 years $89 \%$ vs $90 \%, \mathrm{P}=0.64$ and event free survival $87 \%$ vs $89 \%$ $\mathrm{P}=0.64$ [27].

Regarding acute lymphoblastic leukemia, patients with DS have better prognostic subtypes, with a lower number of chromosomal translocations. Data analysis of more POG (Pediatric Oncology Group) studies revealed the absence of $t(4 ; 11), t(1 ; 19)$ and $T(9 ; 22)$ in patients with DS. These mutations are present in up to $10-13 \%$ in the population without DS and are associated with a poor prognosis. Moreover, patients with DS have a small number of unfavorable clinical and biological characteristics. However, treatment results do not differ significantly in patients with DS from those in the general population, mainly due to treatment induced toxicity. One third of treatment failures in patients with DS are due to treatment toxicities [28]. Similar results have been reported in 2017 by the Polish Study Group for Leukemia and Lymphoma [29]. Data analysis of patients treated for ALL between 2000-2011 at Dana-Faber Institute showed a statistically significant higher rate of adverse events in patients with DS, than in patients without DS: mucositis $(52 \%$ vs $12 \%, \mathrm{p}<0.001)$, thrombosis $(18 \%$ vs $8 \%, \mathrm{p}=0.036)$ and convulsions $(16 \%$ vs $5 \%, \mathrm{p}=0.010)$. Progression free survival and overall survival rates were similar in patients with DS and without DS $(91 \%$ vs $84 \%$, and $97 \%$ vs $91 \%$ ) [30].

The most frequent genetic abnormality found in patients with DS and ALL is CRLF2 overexpression $(62 \%)$, and $50 \%$ of these patients have also JAK 2 mutation $[31,32]$. The prognostic value of these molecular changes in patients with DS remains however unknown [29,33].

\section{Structural chromosomal abnormalities}

WAGR syndrome is a contiguous gene syndrome named after the abnormalities found in patients: Wilms tumor, aniridia, genital abnormalities and mental 
retardation. The syndrome is determined by chromosomal deletion in the $11 \mathrm{p} 13$ region. Clinical features are determined by loss of individual genes: deletion of WT1 is responsible for Wilms tumors [34], while PAX6 deletion is responsible for aniridia [35]. Larger deletion of this region account for the full WAGR syndrome. Children with this syndrome have $50 \%$ risk to develop Wilms tumor [36].

Array comparative genomic hybridization (array $\mathrm{CGH}$ ) is the gold standard laboratory test for detection. Other molecular techniques used for detection of genomic disorders include fluorescence in situ hybridization (FISH), PCR-based studies and Multiple Ligation dependent Probe Amplification (MLPA).

Abdominal ultrasound every 4 months until de age of 5 years is recommended for all patients diagnosed with WAGR syndrome for early diagnosis of Wilms tumors [37]. Positive patients should be included in the screening program. The same screening schedule should be applied in patients with Denys-Drash syndrome. Denys-Drash syndrome is determined by the point mutation at the level of exon 8 or 9 of the WT1 gene and it is characterized by congenital nephropathy, intersex disorders and Wilms tumor [38].

Several studies have shown an increased rate of renal insufficiency in patients with Wilms tumor and WAGR or Denys-Drash syndrome (38-62\%) 20 years after the diagnosis, therefore long-term follow-up of renal function is recommended for these patients $[39,40]$.

\section{Imprinting and growth abnormalities}

Beckwith-Wiedemann syndromeis an overgrowth syndrome characterized by hypoglycemia at birth, organomegaly, macrosomia, macroglossia, abdominal wall defects, and sometimes hemihypertrophy. BWS is determined by multiple genetic and epigenetic abnormalities in two imprinting domains of genes that regulate growth on $11 \mathrm{p} 15$ chromosome. The prevalence of this syndrome is estimated at 1 of 10300-13700 children [41], but this can be an underestimation because of mild phenotypes that usually remain undiagnosed.

The risk of developing tumors in these children is $7.5 \%$ [42]. The risk is concentrated in the first eight years of life, and occurrence of malignant tumors after the age of eight is rare in these patients. The most frequent neoplasia in these children are Wilms tumor and hepatoblastoma, but suprarenalian carcinomas, neuroblastomas and rhabdomyosarcomas have also an increased incidence [43]. Risk factors associated with the development of Wilms tumors in patients with BWS are hemihypertrophy, nephromegaly, uniparental disomy 11 p15 and H19 hypermethylation [44,45].

Patients with uniparental disomy of $11 \mathrm{p} 15.5$ or excessive methylation of the imprinting center H19 have an increased risk of developing malignant tumors, especially Wilms tumors and hepatoblastomas [46].

Screening programs for the early detection of neoplasia in patients diagnosed with BWS differ by cancer center. In some cancer centers the decision of including patients in screening programs and the intensity of the screening is taken according to the results of genetic testing, in other centers all patients with BWS are included in screening programs because of the existing risk of developing neoplasia, although the risk is small. Screening methods used are: 1) abdominal ultrasound every 3 months until the age of 8 years, 2) serum Alphafetoprotein levels every 2-3 months until the age of 4 years for detecting hepatoblastoma 3 ) periodic pulmonary $\mathrm{x}$-ray and urinary homovanilic acid and vanilmandelic acid assays for detection of neuroblastoma [47-49].

\section{Mendelian inheritance of a predisposition to cancer}

Autosomal dominant disorders

The main characteristics of autosomal dominant genetic syndromes are: a) multiple affected generations; b) inheritance from mother or father; c) younger age at diagnosis than in the general population (sporadic cases); d) increased incidence of multiple or bilateral cancers; e) increased incidence of some types of cancer in a family; f) because of variable penetration some mutation carriers may not develop cancer.

Autosomal disorders manifest equally in males and females and can be transmitted by either parent to $50 \%$ of their offspring. Most affected individuals are heterozygous for the mutated gene, with the other copy of the gene having typical (wild-type) sequence. Many autosomal dominant mutations arise de novo, rather than being inherited from a parent.

Retinoblastoma is the most frequent intraocular neoplasia in children, representing $10-15 \%$ of all cancers diagnosed in the first year of life [50]. The main manifestation of retinoblastoma is leukocoria, seen in children under the age of 2 years. At present, survival in developed countries is greater than $95 \%$, however only $50 \%$ of patients with retinoblastoma survive worldwide [51]. The main reason for the low survival rates in underdeveloped and developing countries is late diagnosis, patients presenting with locally advanced or metastatic disease.

Median age at diagnosis is $18-20$ months, early onset for bilateral tumors (12 months) and late onset for unilateral tumors (approximately 24 months) [52]. The majority of cases $(95 \%)$ are diagnosed before the age of 5 years, but rare cases have been reported in the literature in children up to the age of 18 years and even in adults $[53,54]$.

Hereditary forms of retinoblastomas are determined by germline mutations in the RB1 gene on the $13^{\text {th }}$ chromosome. The penetrance is incomplete, 
approximately $90 \%$ of the mutation carriers will develop RB. In some families, lower penetrance has been observed, probably due to partial inactivation of the RB1 gene or due to genetic modifiers [55].

The genetic abnormality is associated with an increased risk for developing other types of cancers: osteosarcomas, soft tissue sarcomas and malignant melanoma [56-58]. A long-term follow-up study of patients with $\mathrm{RB}$ identified a cumulative incidence of $68 \%$ of the second cancer, including epithelial cancers, like lung cancer [59].

The hereditary form of RB is responsible for $40 \%$ of cases, the majority of cases are bilateral, but $15 \%$ of patients with unilateral disease have germline mutations of the RB1 gene [60]. Family history is negative for RB in $80 \%$ of bilateral $\mathrm{RB}$ due to the fact, that the majority of mutations of the RB1 gene are de novo. Germline mutations are present in all cells of the organism from birth (germline mutation of the RB1 locus or deletion of chromosome 13q) [61]. For development of RB a second mutation on the other allele within the retinal cells is needed - according to the "two-hit" model.

$\mathrm{RB} 1$ gene encodes a protein $(\mathrm{Rb})$ which acts as a tumor suppressor $[62,63]$. Rb protein blocks the cell-cycle progression from G1 phase into S phase [64]. Loss of normal function of the protein determines dysregulation of the normal cell-cycle.

Discovery of the RB gene allows for molecular diagnosis and, also gives a response to parents' questions regarding the risk of the disease in future children. Molecular diagnosis is based on chromosome analysis, sequence analysis, MLPA/quantitative multiplex PCR, testing for loss of heterozygosity, methylation analysis.

Siblings of patients with bilateral tumors and germline mutation have a $45 \%$ risk of having the mutation, if one parent is carrier of the mutation. If no parent carries the mutation, there is still a risk of $6 \%$ due to germline mosaicism. Siblings of patients with unilateral disease and no parent carrying the mutation have a $1 \%$ risk to develop retinoblastoma [65]. Siblings of patients with retinoblastoma can be tested at birth and, if positive for the mutation, they have to be included in screening programs for early detection of retinoblastoma. Survivors of retinoblastoma can use DNA testing for prenatal or postnatal diagnosis for their own children. Current screening guidelines recommend ophthalmologic examination under general anesthesia in the first days of life and after that every 4 months in the first 2 years of life for all children carrying the mutation. Ophthalmologic examination is not necessary in children that have not inherited the mutation.

Familial leukemia is historically considered rare, but its real incidence is currently not well known.

Acute myeloblastic leukemia with mutated CEBPA is a hereditary syndrome with autosomal dominant inheritance with a penetrance of almost $100 \%$ and it is determined by the mutation of the CEBPA gene in the chromosomal region 19q13.1. It was first described by Smith at al. in 2004, in a family in which 3 members developed AML through 2 generations [66]. The phenotype is similar with that found in sporadic AML with biallelic mutation of CEBPA: normal karyotype, frequent Auer rods, aberrant expression of CD7, FAB morphology M1 or M2. Age at diagnosis varies largely between 2 and 59 years. It is estimated that $1 \%$ of AML are determined by the CEBPA mutation [67]. Treatment is similar with that used in patients with sporadic AML and the prognosis is favorable, although relapses are possible [68]. Because these patients have an increased risk to develop further forms of leukemia, allogenic transplantation has to be considered for the treatment of AML, but also for replacing stem cells that predispose to leukemia [69]. Taking into account that the penetrance of this syndrome is almost complete, all patients that carry the mutation and haven't developed AML so far have to be screened with regular visits and full blood count.

Familial platelet disorder with propensity to myeloid malignancies is an autosomal dominant syndrome characterized by neonatal thrombocytopenia and increased risk for AML. It is caused by monoallelic mutation of RUNX 1 gene on the 21q22 chromosome band [70]. The estimated lifetime risk for developing acute leukemia is $35-40 \%$ [71]. Reference bone marrow biopsy at diagnosis and follow-up with periodic full blood count and repeated bone marrow biopsy in case of abnormalities is strongly recommended [72].

Gorlin syndrome is a genetic syndrome with autosomal dominant inheritance. Most frequent characteristics found are frontal bossing, hypertelorism, macrocephaly, palmar and plantar pits, jaw odontogenic keratocysts, rib and vertebral anomalies. Most frequent cancers associated with this syndrome are medulloblastoma (most frequent histological subtype is desmoplastic) and basal cell carcinomas. Gorlin syndrome is caused either by the germline mutation of the "patched-1" gene (PTCH1) on the 9q chromosome, a key component of the Sonic hedgehog (SHH) pathway, or by the mutation of the tumor suppressor gene SUFU. During normal cerebellar development, SHH pathway plays an important role in the growth and migration of granule neuron precursor cells. Overactivation of the SHH signaling pathway plays an important role in the pathogenesis of a subset of medulloblastomas both sporadic and associated with Gorlin syndrome. About $3-5 \%$ of patients with Gorlin syndrome develop medulloblastomas, usually before the age of 3 years, most often this being the first clinical manifestation of the syndrome [73]. The risk to develop medulloblastoma is higher in patients with SUFU germline mutations (20 times higher) than in patients with PTCH1 germline 
mutation (less the $2 \%$ will develop medulloblastoma) [74]. Survivors of medulloblastoma with Gorlin syndrome develop multiple basal cell carcinomas in the irradiated field at a time interval between 6 months and 3 years after completion of radiotherapy [75]. Compared to survivors of other cancers, including medulloblastomas, these patients have a higher frequency of radio-induced basal cell carcinomas and a much shorter latency period [76], median latency period in the general population for radio-induced basal cell carcinoma being 21 years [77]. Some authors recommend excluding radiotherapy from the treatment plan in children diagnosed with desmoplastic medulloblastomas under the age of 5 years, due to increased risk of radio-induced cancers (basal cell carcinomas, meningiomas, ependimomas, sarcomas) in the irradiated field and the favorable prognosis of these patients $[78,79]$. Due to the risk of approximately $33 \%$ for medulloblastomas in patients with Gorlin syndrome and SUFU germline mutation, neurological and MRI monitoring every 3 months in the first 2 years, and every 6 months until 3 years is recommended. Other authors recommend annual imaging evaluations until the age of 7 years for all patients with Gorlin syndrome, regardless of the mutation [80].

Turcot syndrome is a historical term, that was first used to describe the association between pediatric central nervous system cancers, especially medulloblastomas and gliomas, and two forms of hereditary colorectal cancer: familial adenomatous polyposis and hereditary nonpolyposis colorectal cancer [81]. Since the first description of the Turcot syndrome in 1959, the discovery of genetic mutations determined splitting Turcot syndrome in two separate genetic syndromes: brain tumorpolyposis type 1 - association between brain tumors and nonpolyposis colorectal cancer determined by MLH1 and MSH2 mutations; and Brain tumor polyposis (BTP) type 2 - association between brain tumors and adenomatous polyposis determined by mutation of APC gene [82].

Familial adenomatous polyposis (FAP) is an autosomal dominant disorder caused by the inactivating mutations of the APC gene (adenomatous polyposis coli) on the $5^{\text {th }}$ chromosome. Germline mutation of one APC allele, associated with the "second hit" mutation of the other allele, will determine complete loss of function of the APC protein and the development of multiple colon polyps [83]. Twenty five percent of cases are represented by de novo mutations of the APC gene, so that in these cases the family history will be negative. More than 1000 different mutations of the APC gene associated with familial adenomatous polyposis have been described $[84,85]$. Studies have shown an association between the localization of the mutation at the level of the APC gene and the severity of the polyposis, the risk of developing cancer, survival, presence and frequency of extracolonic manifestations [86]. Patients with FAP have 92 times higher risk to develop medulloblastomas compared with the general population [87], however the risk seems to be not uniform between patients; the risk is much higher in patients with APC mutations between codons 679-1224 [88]. APC protein is part of a proteic complex of the Wingless signaling pathway. During development, this pathway controls cellular proliferation and differentiation. Loss of APC function will translate in excessive intranuclear accumulation of beta-catenine, an intracellular protein involved in development of medulloblastomas. Clinical and imaging screening programs for early detection of medulloblastomas should be considered for families with APC mutations between codons 679 and 1224 .

Gardner syndrome (GS) is now considered as a subcategory of FAP, characterized by extraintestinal manifestations. Approximately $20 \%$ of FAP patients present common extraintestinal manifestations associated with GS. Benign extraintestinal lesions associated with GS are represented by: osteomas and dental abnormalities, desmoid tumors, adrenal adenomas, nasal angiofibromas. Patients with GS are also at increased risk for extracolonic malignancies: thyroid cancer, pancreatic adenocarcinoma, gastric adenocarcinoma. Of particular interest for pediatric oncology is the increased risk for hepatoblastoma and medulloblastoma in patients with GS $[89,90]$.

Type I Neurofibromatosis is an autosomal dominant genetic disorder with complete penetrance, which affects 1 in 3500 individuals around the world [91]. About half of these are inherited, the rest being de novo mutations [92]. Seventy different mutations responsible for this syndrome have been described. De novo mutations occur in paternally derived chromosomes, and the risk of de novo mutations increases with the age of the father at conception [93]. NF 1 is determined by mutations of the NF 1 gene, located at chromosome 17q11.2 [94]. Neurofibromin, the protein encoded by NF1 gene, is part of the family of guanosine triphosphate hydrolase (GTPase)-activating proteins (GAP), that stimulates the activity of guanosine triphosphate hydrolase in the ras p21 family [95]. Neurofibromin is expressed in tissues like spleen, thymus, kidney, brain. Mutations of NF1 gene determines reduction or loss of protein functions, inducing the clinical characteristics of NF, including the tumors associated with it [96].

Clinical features associated with NF are caféau-lait macules, axillary and inguinal freckling, Lisch nodules (hamartomas of the iris) and neurofibromas. The risk to develop malignant tumors in patients with NK1 is 2.5-4-fold higher that in the general population [97]. Most patients are diagnosed based on clinical features, genetic diagnosis is necessary only in certain situations: 1) prenatal diagnosis of children from affected parents; 2 ) children with no family history, but with multiple café-aulait macules, but no other diagnostic features. 
Plexiform neurofibromas are mainly congenital and develop in the first years of life, preferentially in the craniofacial region, paraspinous region, mediastinum and retroperitoneum [98]. They are invasive tumors, that can determine significant disabilities if invading important structures. Usually, plexiform neurofibromas do not transform into malignant tumors, but a rapid increase in dimension and pain should alert for the possibility of malignant transformation (malignant peripheral nerve sheath tumors) [99]. Treatment consists in most cases of chemotherapy with Vinblastine and low dose Methotrexate. Surgery is reserved for tumors that invade important structures or cause important disabilities. Promising results have been obtained in a phase I trial with Selumetinib, an oral selective mitogen-activated protein kinase (MAPK) kinase (MEK) 1 and 2 inhibitor, as metronomic long-term treatment. Out of 24 patients treated with Selumetinib, 17 had partial response and none had progressive disease [100]. Malignant peripheral nerve sheath tumors are treated according to soft tissue sarcomas protocols.

Optic nerve gliomas affect $15-20 \%$ of children with NF1 younger than 6 years [101]. Pilocytic astrocytoma is the most frequent histology and usually arise along the anterior visual pathway. Only one third of patients have large tumors that determine symptoms [102]. The treatment objective is to improve sight, this is the reason why, for patients without symptoms, treatment is withheld and patients are closely monitored. Carboplatin-based chemotherapy is frequently used. Approximately $14 \%$ of patients obtain an improved sight, but most patients obtain only stable disease [103].

Rhabdomyosarcoma is encountered 20 -fold more frequently than in the general population and is more common in the genitourinary tract [104]. Patients with NF1 also have an increased risk to develop AML, myelodisplasic and myeloproliferative syndromes [105].

Follow-up methods for children with NF1 are controversial. Annual clinical follow-up with physical exam, neurological evaluation and neurofibroma followup are recommended in all guidelines, but routine imaging studies are recommended only by some authors, others recommend imaging studies only if suspicion for tumoral pathology exists $[103,106]$.

Type 2 Neurofibromatosis is an autosomal dominant disorder, much rarer than NF1, which predisposes affected individuals to multiple central nervous system tumors in adulthood.

Von Hippel-Lindau is an autosomal dominant disorder characterized by multiple benign and malignant tumors, with an incidence of 1 in 36000 individuals [107]. Most frequent tumors are hemangiomas of the central nervous system and retina, pheochromocytoma and clear cell renal carcinoma. Other tumors with an increased incidence are endolymphatic sac tumors of the inner ear, pancreatic neuroendocrine tumors, epididymal cysts and serous cystadenomas [108].
Hemangioblastomas are benign tumors that do not invade surrounding tissues and do not metastasize. They affect 60 to 84 percent of patients with VHL [109]. Most commonly involved sites are cerebellum, spinal cord and retina [109]. Median age at diagnosis is 29 years, with an interval between 9 and 78 years. Due to unpredictable growth pattern and in order to decrease surgery-related morbidity, asymptomatic lesions may remain under observation. Surgery is reserved for symptomatic and fast-growing tumors [110]. For non-resectable tumors, stereotactic radiosurgery and fractionated radiotherapy are treatment options [111]. However, a prospective observational study conducted by National Institute of Health showed low local control in tumors treated with stereotactic radiosurgery. No systemic treatment showed efficacy in treatment of hemangioblastomas. In 2011 a pilot study using Sunitinib for treatment of patients with VHL was published. The study didn't show any clinical benefit in hemangioblastoma treatment [109].

About $33 \%$ of patients develop clear cell renal carcinoma, but diagnosis before the age of 20 is extremely rare [109].

Surveillance of pediatric patients with VHL consists in physical and neurological exam, ophthalmologic consult with ophthalmoscopy, audiogram, plasma metanephrine levels, brain, cervical region, spinal cord and thorax MRI. Frequency of these examinations has to take into account patients' age and manifestations of the disorder in other family members [112].

Li-Fraumeni syndrome (LFS) is an inherited autosomal dominant disorder associated with germline mutations of the p53 tumor suppressor gene (TP53) [113]. The gene product can delay cell cycle progression, permitting an opportunity for DNA repair or initiation of programmed cell death (apoptosis). Cells containing damaged DNA can survive and proliferate in the absence of normal activated p53 protein.

Classical definition for LFS requires: one family member diagnosed before 45 years with sarcoma; a firstdegree relative diagnosed with any king of cancer before de age of 45; and a third member of the family (first or second degree relative) with any type of cancer before the age of 45 years or sarcoma at any age [114].

The lifetime risk of developing cancer in patients with LFS has been estimated to be approximately $90 \%$ by the age of 60 [115].

Patients with LFS have a younger age at diagnosis and have a greater risk to develop multiple malignancies [116]. In one study that follow 200 patients with LFS the probability of developing a second primary cancer at 30 years of follow-up reached 57\% [117].

Several reports suggested that radiation-induced cancers are more common in patients with LFS [118]. The theoretical basis for the sensitivity to radiation carcinogenesis is the central role of p53 gene in DNA repair [118]. Taking 
this into account, radiotherapy should be avoided in patients with LFS whenever possible.

Cancers related to LFS are represented by osteosarcoma, chondrosarcoma, rhabdomyosarcoma, brain cancer (most often glioblastoma), leukemia, lymphoma and adrenocortical carcinoma.

Another syndrome named Li-Fraumeni-like (LFL) determined by germline mutations of CHEK 2 has been reported [119]. These families are p53 mutation negative. CHEK2 located at 22q12.1 is in the p53 pathway.

The Birch LFL criteria require: one proband with any childhood cancer or sarcoma, brain tumor or adrenal cortical carcinoma diagnosed before age 45; a first- or seconddegree relative with typical LFS malignancy (Leukemia, sarcoma, breast cancer, brain tumors, adrenal cortex tumor) regardless of age at diagnosis; and a first- or second-degree relative with any cancer diagnosed before 60 years [120].

There are no guidelines regarding screening procedures in the pediatric population. However, general measures including carful physical examination and counseling parents to seek medical attention for any unexplained symptoms by be of use. For adult patients, early screening for breast and colorectal cancers are recommended.

\section{Autosomal recessive disorders}

Xeroderma pigmentosum is an autosomal recessive disorder with complete penetrance, characterized by increased sensitivity to ultraviolet radiation (UVR), early development of UVR-induced skin and mucosal cancers and, in some patients progressive neurodegeneration. The estimated incidence in the United States and West Europe is one in one million births [121]. It is caused by mutations in any of the eight genes responsible for the repair of UVRinduced DNA damage [122]. Squamous cell carcinoma, basal cell carcinomas and melanomas occur in XP patients with an increased frequency and at a younger age. Data published by US National Institute of Health estimated a risk 10000 -fold higher than in the general population for squamous cell and basal cell carcinoma, and 2000-fold higher for malignant melanoma [123].

Median age at diagnosis for squamous cell and basal cell carcinomas is 9 years; however, these tumors may develop as early as 2 years in sun-exposed skin. Median age at diagnosis for melanomas is 22 years. Incidence of oral cancers is 3000-10 000-fold higher than in the general population and most common sites are tip of the tongue and the dorsal tongue [124]. More substances have shown efficacy in chemoprevention for skin cancers in these patients. High-dose systemic retinoids (acitretin and isotretinoin) modulated cell proliferation, differentiation and apoptosis. High dose $(2 \mathrm{mg} / \mathrm{kg} /$ day $)$ isotretinoin decreases the frequency of skin cancers, but some patients develop adverse events that need treatment discontinuation (hepatic toxicity, skeletal abnormalities, mucocutaneous side effects)
[125]. Topic use of Imiquimod and Fluorouracil have also shown efficacy. Fluorouracil is applied daily on the sunexposed skin for 3 weeks, every 3 to 6 months [126].

Fanconi Anemia (FA) is a disorder inherited in an autosomal recessive manner and it is caused by mutations in one of at least 17 different FA genes (FANCA to FANCQ) [127]. It is characterized by pancytopenia, predisposition to malignancy and congenital abnormalities (microcephaly, triangular facies, short neck, hypo/hypertelorism, renal and urinary tract malformations, gonadal malformations). The major function of FA proteins is to maintain genomic stability by repairing DNA interstrand crosslinks (opposite strands of DNA abnormally joined together [128].

Patients are usually diagnosed in childhood, however diagnostic delays and variable manifestations are common and some patients are diagnosed only in adulthood.

Mylodisplastic syndrome and leukemia are common in patients with FA [129]. On the other hand solid tumors are rare in childhood, with the exception of patients harboring biallelic FANCD1/BRCA2 mutations, in whom the likelihood of developing at least one malignancy by seven years is greater the $97 \%$ [130]. Most common tumors in these patients are brain tumors and Wilms tumor.

Other cancer predisposition syndromes with implications in pediatric oncology are: Ataxia telangiectasia (autosomal recessive), Birt-Hogg-Dube syndrome (autosomal dominant), Bloom syndrome (autosomal recessive), Costello syndrome (autosomal dominant), Cowden syndrome (autosomal dominant), Hereditary Neuroblastoma (autosomal dominant), Hereditary Paraganglioma (autosomal dominant), PeutzJeghers syndrome (autosomal dominant), Rhabdoid predisposition syndrome (autosomal dominant), Tuberous sclerosis complex (autosomal dominant).

\section{Conclusions}

Although rare, cancer predisposition hereditary syndromes represent a reality in day to day clinical practice. A high level of susceptibility from the clinician is necessary to diagnose these disorders. A complete medical history with emphasis on family history, personal medical history, including congenital malformations and a complete physical examination may be sufficient for a diagnosis or, if not, for raising a high enough suspicion for referring the patient and their family for genetic consult and diagnosis. Diagnosis of a cancer predisposition hereditary syndrome has a great impact on the patient: inclusion in specific screening programs for early diagnosis of a possible cancer, personalized treatment taking into account the prognosis and possible side effects known for the specific hereditary disorder, long term follow-up; as well as on his family: inclusion in screening programs, prenatal diagnosis, genetic counselling. 


\section{References}

1. Rahman N. Mainstreaming genetic testing of cancer predisposition genes. Clin Med (Lond). 2014;14:436-439.

2. Narod SA, Stiller C, Lenoir GM. An estimate of the heritable fraction of childhood cancer. Br J Cancer. 1991;63:993-999.

3. Wagner J, Portwine C, Rabin K, Leclerc JM, Narod SA, Malkin D. High frequency of germline p53 mutations in childhood adrenocortical cancer. J Natl Cancer Inst. 1994;86:1707-1710.

4. Varley JM, McGown G, Thorncroft M, James LA, Margison GP, Forster G, et al. Are there low-penetrance TP53 alleles? Evidence from childhood adrenocortical tumors.Am J Hum Genet. 1999;65:995-1006.

5. Rush JA, Younge BR, Campbell RJ, MacCarty CS. Optic glioma. Long term follow-up of 85 histopathologically verified cases. Ophthalmology. 1982;89:1213-1219.

6. Lohmann DR, Gallie BL. Retinoblastoma: revisiting the model prototype of inherited cancer.Am J Med GenetC Semin Med Genet. 2004;129C:23-28.

7. Neumann HP, Bausch B, McWhinney SR, Bender BU, Gimm $\mathrm{O}$, Franke G, et al. Germ-line mutations in nonsyndromic pheochromocytoma,N Engl J Med. 2002;346:1459-1466.

8. Craft AW, Parker L, Stiller C, Cole M.Screening for Wilms'tumor in patients with aniridia, Beckwith syndrome, or hemihypertrophy. Med Pediatr Oncol. 1995;24:231-234.

9. Bonaïti-Pellié C, Chompret A, Tournade MF, Hochez J, Moutou C, Zucker JM, et al. Genetics and epidemiology of Wilms' tumor: the French Wilms' tumor study. Med Pediatr Oncol. 1992;20:284-291.

10. Farwell J, Flannery JT. Cancer in relatives of children with central-nervous-system neoplasms. N Engl J Med. 1984;311:749-753.

11. Gold EB, Leviton A, Lopez R, Austin DF, Gilles FH, Hedley-Whyte ET, et al. The role of family history in risk of childhood brain tumors. Cancer. 1994;73:1302-1311.

12. Avet-Loiseau H, Mechinaud F, Harousseau JL. Clonal hematologic disorders in Down syndrome. A review. J Pediatr Hematol Oncol. 1995;17:19-24.

13. Zipursky A, Transient leukaemia--a benign form of leukaemia in newborn infants with trisomy 21. $\mathrm{Br} \mathrm{J}$ Haematol. 2003;120:930-938.

14. Hasle H, Clemmensen IH, Mikkelsen M. Risks of leukaemia and solid tumors in individuals with Down's syndrome. Lancet. 2000;355:165-169.

15. Nakagawa T, Nishida H, Arai T, Yamada T, Fukuda M, Sakamoto S. Hyperviscosity syndrome with transient abnormal myelopoiesis in Down syndrome. J Pediatr. 1988;112:58-61.

16. Miyauchi J, Ito Y, Kawano T, Tsunematsu Y, Shimizu K. Unusual diffuse liver fibrosis accompanying transient myeloproliferative disorder in Down's syndrome: a report of four autopsy cases and proposal of a hypothesis. Blood. 1992;80:1521-1527.

17. Gamis AS, Hilden JM. Transient myeloproliferative disorder, a disorder with too few data and many unanswered questions: does it contain an important piece of the puzzle to understanding hematopoiesis and acute myelogenous leukemia? J Pediatr Hematol Oncol. 2002;24:2-5.

18. Zipursky A, Poon A, Doyle J. Leukemia in Down syndrome: a review. Pediatr Hematol Oncol. 1992;9:139-149.

19. Yamaguchi Y, Fujii H, Kazama H, Iinuma K, Shinomiya $\mathrm{N}$, Aoki T. Acute myeloblastic leukemia associated with trisomy 8 and translocation $8 ; 21$ in a child with Down syndrome. Cancer Genet Cytogenet. 1997;97:32-34.

20. Wong KY, Jones MM, Srivastava AK, Gruppo RA. Transient myeloproliferative disorder and acute nonlymphoblastic leukemia in Down syndrome. J Pediatr. 1988;112:18-22.

21. Hitzler JK, Cheung J, Li Y, Scherer SW, Zipursky A. GATA1 mutations in transient leukemia and acute megakaryoblastic leukemia of Down syndrome. Blood. 2003;101:4301-4304.

22. Gamis AS, Smith FO. Transient myeloproliferative disorder in children with Down syndrome: clarity to this enigmatic disorder. Br J Haematol. 2012;159:2777-2787.

23. Slordahl SH, Gustafsson G, Jonmundsson G, et al. Down's syndrome (DS) and acute myelogenous leukemia (AML). A population based study in the five Nordic countries. Med Ped Oncol. 1992; 20:373.

24. Ravindranath Y, Abella E, Krischer JP, Wiley J, Inoue $\mathrm{S}$, Harris $\mathrm{M}$, et al. Acute myeloid leukemia (AML) in Down's syndrome is highly responsive to chemotherapy: experience on Pediatric Oncology Group AML Study 8498. Blood. 1992;80:2210-2214.

25. Taub JW, Matherly LH, Stout ML, Buck SA, Gurney JG, Ravindranath Y. Enhanced metabolism of 1-betaD-arabinofuranosylcytosine in Down syndrome cells: a contributing factor to the superior event free survival of Down syndrome children with acute myeloid leukemia. Blood. 1996;87:3395-3403.

26. O’Brien MM, Taub JW, Chang MN, Massey GV, Stine KC, Raimondi SC, et al. Cardiomyopathy in children with Down syndrome treated for acute myeloid leukemia: a report from the Children's Oncology Group Study POG 9421. J Clin Oncol. 2008;26:414-420.

27. Uffmann $M$, Rasche $M$, Zimmermann $M$, von Neuhoff C, Creutzig U, Dworzak M, et al. Therapy reduction in patients with Down syndrome and myeloid leukemia: the international ML-DS 2006 trial. Blood. 2017;129:33143321.

28. Pui CH, Raimondi SC, Borowitz MJ, Land VJ, Behm FG, Pullen DJ, et al, Immunophenotypes and karyotypes of leukemic cells in children with Down syndrome and acute lymphoblastic leukemia. J Clin Oncol. 1993;11:1361-1367.

29. Zawitkowska J, Odój T, Drabko K,Zaucha-Prażmo A, Rudnicka J, Romiszewski M, et al. Outcome of acute lymphoblastic leukemia in children with Down syndromePolish pediatric leukemia and lymphoma study group report. Pediatr Hematol Oncol. 2017;34:199-205.

30. Athale UH, Puligandla M, Stevenson KE, Asselin B, Clavell LA, Cole PD, et al. Outcome of children and adolescents with Down syndrome treated on DanaFarber Cancer Institute Acute Lymphoblastic Leukemia Consortium protocols 00-001 and 05-001. Pediatr Blood Cancer. 2018;65:e27256. 
31. Maloney KW, Caroll WL, Caroll AJ, Devidas M, Borowitz MJ, Martin PL, et al. Down syndrome childhood acute lymphoblastic leukemia has a unique spectrum of sentinel cytogenetic lesions that influences treatment outcome: a report from the Children's Oncology Group. Blood. 2010;116:1045-1050

32. Hertzberg L, Vendramini E, Ganmore I, Cazzaniga G, Schmitz M, Chalker J, et al. Down syndrome acute lymphoblastic leukemia, a highly heterogeneous disease in which aberrant expression of CRLF2 is associated with mutated JAK2: a report from the International BFM Study Group. Blood. 2010;115:1006-1017.

33. Mullighan CG, Collins-Underwood JR, Phillips LA, Loudin MG, Liu W, Zhang J, et al. Rearrangement of CRLF2 in B-progenitor- and Down syndrome-associated acute lymphoblastic leukemia. Nat Genet. 2009;41:12431246.

34. Breslow NE, Norris R, Norkool PA, Kang T, Beckwith JB, Perlman EJ, et al. Characteristics and outcomes of children with the Wilms tumor-Aniridiasyndrome: a report from the National Wilms Tumor Study Group. J Clin Oncol. 2003;21:4579-4585.

35. Ton CC, Hirvonen H, Miwa H, Weil MM, Monaghan P, Jordan T, et al. Positional cloning and characterization of a paired box- and homeobox-containing gene from the aniridia region. Cell. 1991;67:1059-1074.

36. Scott RH, Stiller CA, Walker L, Rahman N. Syndromes and constitutional chromosomal abnormalities associated with Wilms tumor. J Med Genet. 2006;43:705-715.

37. Green DM, Breslow NE, Beckwith JB, Norkool P. Screening of children with hemihypertrophy, aniridia, and Beckwith-Wiedemann syndrome in patients with Wilms tumor: a report from the National Wilms Tumor Study. Med Pediatr Oncol. 1993;21:188-192.

38. Pelletier J, Bruening W, Li FP, Haber DA, Glaser T, Housman DE. WT1 mutations contribute to abnormal genital system development and hereditary Wilms'tumor. Nature. 1991;353:431-434.

39. Breslow NE, Takashima JR, Ritchey ML, Strong LC, Green DM. Renal failure in the Denys-Drash and Wilms' tumoraniridia syndromes. Cancer Res. 2000;60:4030-4032.

40. Breslow NE, Collins AJ, Ritchey ML, Grigoriev YA, Peterson SM, Green DM. End stage renal disease in patients with Wilms tumor: results from the National Wilms Tumor Study Group and the United States Renal Data System. J Urol. 2005;174(5):1972-1975.

41. Mussa A, Russo S, De Crescenzo A, Chiesa N, Molinatto C, Selicorni A, et al. Prevalence of Beckwith-Wiedemann syndrome in North West of Italy. Am J Med Genet A. 2013;161A:2481-2486.

42. Wiedemann HR.Tumors:an hemihypertrophy associated with Wiedemann-Beckwith syndrome. Eur J Pediatr. 1983;141:129.

43. Cohen MMJr. Beckwith-Wiedemann syndrome: historical, clinicopathological, and etiopathogenetic perspectives. Pediatr Dev Pathol. 2005;8:287-304.

44. DeBaun MR, Siegel MJ, Choyke PL. Nephromegaly in infancy and early childhood: a risk for Wilms tumor in Beckwith-Wiedemann syndrome. J Pediatr. 1998;132(3 Pt 1):401-404.

45. Weksberg R, Shuman C, Smith AC. Beckwith-Wiedemann syndrome. Am J Med Genet C Semin Med Genet. 2005; 15; 137C:12-23.

46. Scott RH, Douglas J, Baskcomb L, Huxter N, Barker $\mathrm{K}$, Hanks S, et al. Constitutional 11p15 abnormalities, including heritable imprinting center mutations, cause nonsyndromic Wilms tumor. Nat Genet. 2008;40:13291334.

47. Kalish JM, Doros L, Helman LJ, Hennekam RC, Kuiper RP, Maas SM, et al. Surveillance Recommendations for Children with Overgrowth Syndromes and Predisposition to Wilms Tumors and Hepatoblastoma. Clin Cancer Res. 2017;23:e115-e122.

48. Brioude F, Lacoste A, Netchine I, Vazquez MP, Auber F, Audry G, et al. Beckwith-Wiedemann syndrome: growth pattern and tumor risk according to molecular mechanism, and guidelines for tumor surveillance. Horm Res Paediatr. 2013;80:457-465.

49. Clericuzio CL, Martin RA. Diagnostic criteria and tumor screening for individuals with isolated hemihyperplasia. Genet Med. 2009;11:220-222.

50. Pichi F, Lembo A, De Luca M, Hadjistilianou T, Nucci P. Bilateral retinoblastoma: clinical presentation, management and treatment. Int Ophthalmol. 2013;33:589-593.

51. Howlader N, Noone AM, Krapcho M, et al. SEER Cancer Statistics Review, 1975-2012, National Cancer Institute, Bethesda. Available from: https://seer.cancer.gov/archive/ csr/1975_2012/results_merged/sect_28_childhood_cancer. pdf

52. Abramson DH, Beaverson K, Sangani P, Vora RA, Lee TC, Hochberg HM, et al. Screening for retinoblastoma: presenting signs as prognosticators of patient and ocular survival. Pediatrics. 2003;112(6Pt 1):1248-1255.

53. Shields JA, Michelson JB, Leonard BC, Thompson R. Retinoblastoma in a eighteen-year-old male. J Pediatr Ophtalmol. 1976;13:274-277.

54. Biswas J. Unilateral retinoblastoma in an adult. Ophtalmology. 1997;104:1728.

55. Rushlow D, Piovesan B, Zhang K, Prigoda-Lee NL, Marchong MN, Clark RD, et al. Detection of mosaic RB1 mutations in families with retinoblastoma. Hum Mutat. 2009;30:842-851.

56. Wong FL, Boice JDJr, Abramson DH, Tarone RE, Kleinerman RA, Stovall M, et al. Cancer incidence after retinoblastoma. Radiation dose and sarcoma risk.JAMA. 1997;278:1262-1267.

57. DerKinderen DJ, Koten JW, Nagelkerke NJ, Tan KE, Beemer FA, Den Otter W. Non-ocular cancer in patients with hereditary retinoblastoma and their relatives. Int $\mathrm{J}$ Cancer. 1988;41:499-504.

58. Eng C, Li FP, Abramson DH, Ellsworth RM, Wong FL, Goldman MB, et al. Mortality from second tumors among long-term survivors of retinoblastoma. J Natl Cancer Inst. 1993;85:1121-1128. 
59. Fletcher O, Easton D, Anderson K, Gilham C, Jay M, Peto J. Lifetime risks of common cancers among retinolastoma survivors. J Natl Cancer Inst. 2004;96:357-363.

60. Brichard B, Heusterspreute M, De Potter P, Chantrain C, Vermylen C, Sibille C, et al. Unilateral retinoblastoma, lack of familial history and older age does not exclude germline RB1 gene mutation. Eur J Cancer. 2006;42:65-72.

61. Kivelä T, Tuppurainen K, Riikonen P, Vapalahti M. Retinoblastoma associated with chromosomal 13q14 deletion mosaicism. Ophthalmology. 2003; 110:1983-1988.

62. Fung YK, Murphree AL, T'Ang A, Qian J, Hinrichs SH, Benedict WF. Structural evidence for the authenticity of the human retinoblastoma gene. Science. 1987;236:1657-1661.

63. Lee WH, Bookstein R, Hong F, Young LJ, Shew JY, Lee EY. Human retinoblastoma susceptibility gene: cloning, identification, and sequence. Science. 1987;235:13941399.

64. Goodrich DW, Wang NP, Qian YW, Lee EY, Lee WH. The retinoblastoma gene product regulates progression through the G1 phase of the cell cycle. Cell. 1991;67:293-302.

65. Musarella MA, Gallie BL. A simplified scheme for genetic counseling in retinoblastoma. J Pediatr Ophtalmol Strabismus. 1987;24:124-125.

66. Smith ML, Cavenagh JD, Lister TA, Fitzgibbon J. Mutation of CEBPA in familial acute myeloid leukemia. N Engl J Med. 2004;351:2403-2407.

67. TaskesenE, Bullinger L, Corbacioglu A, Sanders MA, Erpelinck CA, Wouters BJ, et al. Prognostic impact, concurrent genetic mutations, and gene expression features of AML with CEBPA mutations in a cohort of 1182 cytogenetically normal AML patients: further evidence of CEBPA double mutant AML as a distinctive disease entity. Blood. 2011;117:2469-2475.

68. Tawana K, Wang J, Renneville A, Bödör C, Hills R, Loveday $\mathrm{C}$,et al. Disease evolution and outcomes in familial AML with germline CEBPA mutations. Blood. 2015;126:12141223.

69. Stelljes M, Corbacioglu A, Schlenk RF, Döhner K, Frühwald $\mathrm{MC}$, Rossig C, et al. Allogeneic stem cell transplant to eliminate germline mutations in the gene for CCAATenhancer-binding protein $\alpha$ from hematopoietic cells in a family with AML. Leukemia. 2011;25:1209-1210.

70. Song WJ, Sullivan MG, Legare RD,Hutchings S, Tan $\mathrm{X}$, Kufrin D, et al. Haploinsufficiency of CBFA2 causes familial thrombocytopenia with propensity to develop acute myelogenous leukaemia. Nat Genet. 1999;23:166175.

71. Owen CJ, Toze CL, Koochin A, Forrest DL, Smith CA, Stevens JM, et al. Five new pedigrees with inherited RUNX1 mutations causing familial platelet disorder with propensity to myeloid malignancy. Blood. 2008;112:46394645.

72. Liew E, Owen C. Familial myelodisplastic syndrome: a review of the literature. Haematologica. 2011;96:15361542 .

73. Amlashi SF, Riffaud L, Brassier G, Morandi X. Nevoid basal cell carcinoma syndrome: relation with desmoplatic medulloblastoma in infancy. A population-based study and review of the literature. Cancer. 2003;98:618-624.

74. Smith MJ, Beetz C, Williams SG, Bhaskar SS, O'Sullivan $\mathrm{J}$, Anderson B,et al. Germline mutations in SUFU cause Gorlin syndrome-associated childhood medulloblastoma and redefine the risk associated with PTCH1 mutations. J Clin Oncol. 2014;32:4155-4161.

75. Strong LC. Genetic and environmental interactions. Cancer. 1977;40(4 Suppl):1861-1866.

76. Strong LC. Theories of pathogenesis: Mutation and cancer. Genetics of Human cancer. 1977; pp. 401-414.

77. Martin H, Strong E, Spiro RH. Radiation-induced skin cancer of the head and neck. Cancer. 1970;25:61-71.

78. Grill J, Sainte-Rose C, Jouvet A, Gentet JC, Lejars O, Frappaz D, et al. Treatment of medulloblastoma with postoperative chemotherapy alone: an SFOP prospective trial in young children. Lancet Oncol. 2005;6:573-580.

79. Rutkowski S, Bode U, Deinlein F, Ottensmeier H, WarmuthMetz M, Soerensen N, et al. Treatment of early childhood medulloblastoma by postoperative chemotherapy alone. $\mathrm{N}$ Engl J Med. 2005;352:978-986.

80. Foulkes WD, Kamihara J, Evans DGR, Brugières L, Bourdeaut F, Molenaar JJ,et al. Cancer Surveillance in Gorlin Syndrome and Rhabdoid Tumor Predisposition Syndrome.Clin Cancer Res. 2017;23:e62-e67.

81. Turcot J, Despres JP, St Pierre F. Malignant tumors of the central nervous system associated with familial polyposis of the colon: report of two cases. Dis Colon Rectum. 1959;2:465-468.

82. Paraf F, Jothy S, Van Meir EG. Brain tumor-polyposis syndrome: two genetic diseases? J Clin Oncol. 1997; 15:2744-2758.

83. Lamlum H, Ilyas M, Rowan A, Clark S, Johnson V, Bell $\mathrm{J}$, et al. The type of somatic mutation at APC in familial adenomatous polyposis is determined by the site of the germline mutation: a new facet to Knudson's 'two-hit' hypothesis. Nat Med. 1999;5:1071-1075.

84. Laurent-Puig P, Béroud C, Soussi T. APC gene: database of germline and somaticmutations in human tumors and cell lines. Nucleic Acids Res. 1998;26:269-270.

85. Moisio AL, Järvinen H, Peltomäki P. Genetic and clinical characterisation of familial adenomatous polyposis: a population based study. Gut. 2002;50:845-850.

86. Heinen CD. Genotype to phenotype: analyzing the effects of inherited mutations in colorectal cancer families. Mutat Res. 2010;693:32-45.

87. Hamilton SR, Liu B, Parsons RE, Papadopoulos N, Jen J, Powell SM, et al. The molecular basis of Turcot's syndrome. N Engl J Med. 1995;332:839-847.

88. Attard TM, Giglio P, Koppula S, Snyder C, Lynch HT. Brain tumors in individuals with familial adenomatous polyposis: a cancer registry experience and pooled case report analysis. Cancer. 2007;109:761-766.

89. Giardiello FM, Petersen GM, Brensinger JD, Luce MC, Cayouette MC, Bacon J, et al. Hepatoblastoma and APC gene mutation in familial adenomatous polyposis. Gut. 
1996;39:867-869.

90. Surun A, Varlet P, Brugières L, Lacour B, Faure-Couter $\mathrm{C}$, Leblond $\mathrm{P}$, et al. Medulloblastomas associated with an APC germline pathogenic variant share the good prognosis of CTNNB1-mutated medulloblastomas. Neuro Oncol. 2020;22(1):128-138.

91. Weinberg RA. The biology of cancer. New York: Garland Science; 2007: pp. 209-211.

92. Evans DG, Howard E, Giblin C, Clancy T, Spencer H, Huson SM, et al. Birth incidence and prevalence of tumorprone syndromes: estimates from a UK family genetic register service. Am J Med Genet A. 2010;152A:327-332.

93. Stephens K, Kayes L, Riccardi VM, Rising M, Sybert VP, Pagon RA. Preferential mutation of theneurofibromatosis type 1 gene in paternally derived chromosomes. Hum Genet. 1992;88:279-282.

94. Ledbetter DH, Rich DC, O'ConnellP, Leppert M, Carey JC. Precise localization of NF1 to $17 \mathrm{q} 11.2$ by balanced translocation. Am J Hum Genet. 1989;44:20-24.

95. Martin GA, Viskochil D, Bollag G, McCabe PC, Crosier WJ, Haubruck H, et al. The GAP-related domain of the neurofibromatosis type 1 gene product interacts with ras p21. Cell. 1990;63(4):843-849.

96. Shen MH, Harper PS, Upadhyaya M. Molecular genetics of neurofibromatosis type 1(NF1). J Med Genet. 1996;33:217.

97. Sørensen SA, Mulvihill JJ, Nielsen A. Long-term followup of von Recklinghausen neurofibromatosis. Survival and malignant neoplasms. N Engl J Med. 1986;314:1010-1015.

98. Bass JC, Korobkin M, Francis IR, Ellis JH, Cohan RH. Retroperitoneal plexiform neurofibromas: CT findings. AJR Am J Roentgenol 1994;163:617-620.

99. Serletis D, Parkin P, Bouffet E, Shroff M, Drake JM, Rutka JT. Massive plexiform neurofibromas in childhood:natural history and management issues. J Neurosurg. 2007;106(5 Suppl):363-367.

100. Dombi E, Baldwin A, Marcus LJ, Fisher MJ, Weiss B, Kim A, et al. Activity of Selumetinib in Neurofibromatosis Type 1-Related Plexiform Neurofibromas. N Engl J Med. 2016;375:2550-2560.

101. Lewis RA, Gerson LP, Axelson KA, Riccardi VM, Whitford RP. von Recklinghausen neurofibromatosis.II. Incidence of optic gliomata.Ophtalmology. 1984;91:929-935.

102. Fisher MJ, Loguidice M, Gutmann DH, Listernick R, Ferner RE, Ullrich NJ, et al. Visual outcomes in children with neurofibromatosis type 1-associated optic pathway glioma following chemotherapy: a multicenter retrospective analysis. Neuro Oncol. 2012;14:790-797.

103. Hersh JH; American Academy of Pediatrics Committee on Genetics. Health supervision for children with neurofibromatosis. Pediatrics. 2008;121:633-642.

104. Sung L, Anderson JR, Arndt G, Raney RB, Meyer WH, Pappo AS. Neurofibromatosis in children with Rhabdomyosarcoma: a report from the Intergroup Rhabdomyosarcoma study IV. J Pediatr. 2004;144:666668 .
105. O'Marcaigh AS, Shannon KM. Role of the NF1 gene in leukemogenesis and myeloid growth control. J Pediatr Hematol Oncol. 1997;19:551-554.

106. Wolkenstein P, Frèche B, Zeller J, Revuz J. Usefulness of screening investigations in neurofibromatosis type 1 . A study of 152 patients. Arch Dermatol. 1996;132:13331336.

107. Maher ER, Yates JR, Harries R, Benjamin C, Harris R, Moore AT, et al. Clinical features and natural history of von Hippel-Lindau disease. Q J Med. 1990;77:1151-1163.

108. Lonser RR, Kim HJ, Butman JA, Vortmeyer AO, Choo DI, Oldfield EH. Tumors of the endolymphatic sac in von Hippel-Lindau disease. N Engl J Med. 2004;350:24812486.

109. Jonasch E, McCutcheon IE, Waguespack SG, Wen S, Davis DW, Smith LA, et al. Pilot trial of sunitinib therapy in patients with von Hippel-Lindau disease. Ann Oncol. 2011;22:2661-2666.

110. Lonser RR, Weil RJ, Wanebo JE, DeVroom HL, Oldfield EH. Surgical management of spinal cord hemangioblastomas in patients with von Hippel-Lindau disease. J Neurosurg. 2003;98:106-116.

111. Kano H, Shuto T, Iwai Y, Sheehan J, Yamamoto M, McBride HL, et al. Stereotactic radiosurgery for intracranial hemangioblastomas: a retrospective international outcome study. J Neurosurg. 2015;122:1469-1478.

112. Rednam SP, Erez A, Druker H,Janeway KA, Kamihara J, Kohlmann WK, et al. Von Hippel-Lindau and Hereditary Pheochromocytoma/Paraganglioma Sydromes: Clinical Features, Genetics, and Surveillance Recommendations in Childhood. Clin Cancer Res. 2017;23:e68-e75.

113. Malkin D. Li-Fraumeni syndrome. Genes Cancer. 2011;2:475-484.

114. Li FP, Fraumeni JF Jr. Soft-tissue sarcomas, breast cancer, and other neoplasms.A familial syndrome? Ann Intern Med. 1969;71:747-752.

115. Mai PL, Best AF, Peters JA, DeCastro RM, Khincha PP, Loud JT, et al. Risks of first and subsequent cancers among TP53 mutation carriers in the National Cancer Institute LiFraumeni syndrome cohort. Cancer. 2016;122:3673-3681.

116. Nichols KE, Malkin D, Garber JE, Fraumeni JF Jr, Li FP. Germ-line p53 mutations predispose to a wide spectrum of early-onset cancers. Cancer Epidemiol Biomarkers Prev. 2001;10:83-87.

117. Hisada M, Garber JE, Fung CJ, Fraumeni JF Jr, Li FP. Multiple primary cancers in families with Li-Fraumeni syndrome. J Natl Cancer Inst. 1998;90:606-611.

118. Heymann S, Delaloge S, Rahal A, Caron O, Frebourg T, Barreau L, et al. Radio-induced malignancies after breast cancer postoperative radiotherapy in patiens with LiFraumeni syndrome. Radiat Oncol. 2010;5:104.

119. Varley J. TP53, hChk2, and the Li-Fraumeni syndrome. Methods Mol Biol. 2003;222:117-129.

120. Birch JM, Hartley AL, Tricker KJ, Prosser J, Condie A, Kelsey AM, et al. Prevalence and diversity of constitutional mutations in the p53 gene among $21 \mathrm{Li}$-Fraumeni families. Cancer Res. 1994;54:1298-1304. 
121. Kleijer WJ, Laugel V, Berneburg M, Nardo T, Fawcett $\mathrm{H}$, Gratchev A, et al. Incidence of DNA repair dificiency disorders in western Europe: Xeroderma pigmentosum, Cockayne syndrome and trichothiodystrophy. DNA Repair(Amst). 2008;7:744-750.

122. Cleaver JE. Defective repair replication of DNA in xeroderma pigmentosum. 1968. DNA Repair (Amst.). 2004;3:183-187.

123. Kraemer KH, DiGiovanna JJ. Forty years of research on xeroderma pigmentosum at the US National Institutes of Health. Photochem Photobiol. 2015;91:452-459.

124. Mahindra P, DiGiovanna JJ, Tamura D, Brahim JS, Hornyak TJ, Stern JB, et al. Skin cancers, blindness, and anterior tongue mass in African brothers. J Am Acad Dermatol. 2008;59:881-886.

125. Kraemer KH, DiGiovanna JJ, Moshell AN, Tarone RE, Peck GL. Prevention of skin cancer in xeroderma pigmentosum with the use of oral isotretinoin. N Engl $\mathrm{J}$
Med. 1988;318:1633-1637.

126. Lambert WC, Lambert MW. Development of effective skin cancer treatment and prevention in xeroderma pigmentosum.Photochem Photobiol, 2015;91:457-483.

127. De Rocco D, Bottega R, Cappelli E, Cavani S, Criscuolo M, Nicchia E, et al. Molecular analysis of Fanconi anemia: the experience of the Bone Marrow Failure Study Group of the Italian Association of Pediatric Onco-Hematology. Haematologica. 2014;99:1022-1031.

128. Kee Y, D'Andrea AD. Expanded roles of the Fanconi anemia pathway in preserving genomic stability. Genes Dev. 2010;24:1680-1694.

129. Alter BP. Fanconi anemia and the development of leukemia. Best Pract Res Clin Haematol. 2014;27:214-221.

130. Malric A, Defachelles AS, Leblanc T, Lescoeur B, Lacour B, Peuchmaur M, et al. Fanconi anemia and solid malignancies in childhood: a national retrospective study. Pediatr Blood Cancer. 2015;62:463-470. 